\title{
Efektivitas dan Persepsi Pelaksanaan Penyuluhan Pertanian pada Masa Pandemi Covid 19
}

Mohamad Ikbal Bahua

Fakultas Pertanian Universitas Negeri Gorontalo, Email: mohamad.bahua@ung.ac.id

\section{Article Info}

Article history:

Received 21 March 202

Received in revised from 24 May 2021

Accepted 03 June 2021

DOI:

https://doi.org/10.32938/ag.v6i3.1358

Keywords:

Effectiveness of Extension

Perception of Farmers

Covid Pandemic 19

\begin{abstract}
Abstrak
This study aims (1) to analyze the effectiveness of the implementation of agricultural extension and (2) to analyze farmers' perceptions of the implementation of the agricultural extension during the Covid 19 pandemic. The research was conducted in North Gorontalo Regency, through a survey method from June to September 2020. The sample of research respondents was 60 corn farmers who were taken by purposive sampling. To determine the effectiveness and perception of the research data, the analysis used semantic differential analysis. The results showed that the implementation of the agricultural extension during the Covid 19 pandemic was "effective" because it was carried out under the objectives of the counseling program and health protocol guidelines which had an impact on changing mindsets, attitudes, and abilities of farmers in managing farming during the Covid 19 pandemic. Farmers' perceptions of the implementation of the agricultural extension during the Covid 19 pandemic were "Good" because the implementation of the extension was based on the competence, independence, and motivation of the extension agents, which are key factors in the quality of agricultural extension personnel in achieving the objectives of the extension institution.
\end{abstract}

\section{Pendahuluan}

Penyuluhan pertanian merupakan pendidikan non formal yang ditujukan untuk meningkatkan peran petani dalam meningkatkan produksi pertanian sesuai dengan keadaan lingkungan pertanian di sekitar petani. Penyuluhan pertanian dilakukan sebagai solusi bagi permasalahan yang dihadapi petani dalam usahatani yang disesuaikan dengan perkembangkan ilmu pengetahuan dan teknologi. Efektivitas dan persepsi pelaksanaan penyuluhan ditunjukkan oleh adanya perubahan pengetahuan, keterampilan, dan sikap petani dalam melaksanakan usahatani.

Menurut Harper et al., (2021) penyuluhan pertanian merupakan proses pembelajaran bagi petani dan keluarganya serta pelaku usaha pertanian lainnya agar mereka tahu, mau dan mampu menolong dan mengorganisasikan dirinya dalam mengakses pasar, teknologi pertanian, permodalan dan sumber daya lainnya sebagai upaya untuk meningkatkan produktivitas, efisiensi dan efektif usaha, pendapatan dan kesejahteraannya.

Taylor \& Suhas (2018) menjelaskan bahwa dalam penyelenggaraan penyuluhan, penyuluh pertanian memposisikan dirinya sebagai fasilitator, dinamisator, motivator dan komunikator agar petani mampu mengadopsi teknologi pertanian yang disampaikan oleh penyuluh. Menurut Hunt et al., (2014), bahwa penyuluh pertanian lebih berupaya mengembangkan materi, metode dan media penyuluhan serta selalu meningkatkan ilmu pengetahuan dan keterampilannya pada bidang yang multidispilin, agar penyuluh lebih memahami kebutuhan petani dalam melaksanakan usahatani.

Menurut Slimi et al.,(2021) pentingnya penyuluhan pertanian diawali oleh kesadaran akan adanya kebutuhan petani untuk mengembangkan dirinya dalam menjalankan usahatani dengan baik agar lebih mampu meningkatkan pendapatan dan kesejahteraan hidupnya. Kegiatan penyuluhan pertanian perlu dikembangkan sebagai dasar menggerakkan kesadaran dan partisipasi petani dalam proses pembangunan agar mereka memiliki kemampuan menolong dirinya sendiri untuk mencapai tujuan perbaikan mutu hidup dan kesejahteraan yang dicita-citakan (Cook et al., 2021).

Kuehne et al., (2017), menjelaskan bahwa penyuluh pertanian berusaha mengidentifikasi potensi dan kebutuhan petani serta menerapkan pendekatan penyuluhan yang sesuai dengan kebutuhan petani. Dengan demikian kemampuan kualitas penyuluh perlu ditingkatkan pada berbagai bidang pendidikan dan pelatihan untuk meningkatkan kompetensi, motivasi dan kinerja penyuluh, dalam membantu petani untuk meningkatkan produksi usahatani dan kesejahteraannya (Bhandari et al., 2019).

Penyelenggaraan penyuluhan pertanian dalam meningkatkan produksi usahatani jagung berhubungan erat dengan perkembangan teknologi pertanian, terutama yang berhubungan dengan penyediaan sarana produksi pertanian, seperti; benih, pupuk dan pestisida (Liu et al., 2019). Ketersediaan sarana produksi tersebut diupayakan pada awal musim tanam yang dibarengi dengan ketersediaan modal usahatani serta jaminan pemasaran hasil usahatani. Kemampuan 
petani menjalankan usahatani jagung perlu mendapat pendampingan dari penyuluh pertanian dari proses pengolahan tanah sampai dengan pelaksanaan panen (Johnson et al., 2019). Pendampingan ini membutuhkan pengetahuan dan pengalaman penyuluh pada kemampuan teknis budidaya jagung.

Corona virus (Corona Virus Disease 2019 = Covid 19) adalah kumpulan virus yang bisa menginfeksi sistem pernapasan. Pada banyak kasus, virus ini hanya menyebabkan infeksi pernapasan ringan, seperti flu. Namun, virus ini juga bisa menyebabkan infeksi pernapasan berat, seperti infeksi paru-paru (pneumonia). Virus ini menular melalui percikan dahak (droplet) dari saluran pernapasan, misalnya ketika berada di ruang tertutup yang ramai dengan sirkulasi udara yang kurang baik atau kontak langsung dengan droplet (Acter et al., 2020). Virus corona telah menjangkit secara masif, sehingga virus corona disebut sebagai pandemi. Indonesia menjadi salah satu wilayah yang telah terjangkit pandemi ini dengan kasus pertama yang ditemukan pada tanggal 2 Maret 2020. Virus ini tidak hanya mengancam kesehatan namun juga berdampak yang cukup signifikan pada sektor perekonomian dan kesehatan.

Sektor pertanian menjadi pengaman dan memiliki peluang dalam menghadapi wabah Covid19, sektor pertanian berperan penting dalam pemenuhan ekonomi sebagian besar masyarakat. Untuk itu perlunya pengembangan sektor pertanian termasuk berbagai kebijakan pemerintah dalam upaya mempertahankan eksistensi sektor pertanian dalam usaha pemenuhan kebutuhan masyarakat pada masa pandemi Covid-19 (Khairad, 2020).

Kualitas pelaksanaan penyuluh pertanian dalam membantu petani mengelola usahatani tidak lepas dari kinerja, kompetensi, kemandirian, dan motivasi penyuluh dalam melaksanakan tugas pokok dan fungsinya sebagai penyuluh pertanian pada masa pandemi Covid 19 yang implementasinya disesuaikan dengan protokol kesehatan, sehingga penyuluh pertanian perlu mengetahui ilmu epidemiologi yang berhubungan dengan penyebaran Covid 19 (Krausmann \& Amos, 2021).

\section{Metode}

Penelitian dilaksanakan di Kabupaten Gorontalo Utara melalui metode survei pada bulan Juni sampai dengan September 2020. Sampel responden penelitian 60 orang petani jagung yang diambil secara purposive sampling. Sumber data pada penelitian ini adalah data primer dan data sekunder. Data primer bersumber dari hasil wawancara langsung secara terstruktur dengan petani melalui panduan kuesioner. Data sekunder merupakan data pendukung yang bersumber dari dinas instansi terkait, seperti: dinas pertanian dan kantor BP3K. Variabel penelitian karakteristik petani, terdiri dari: umur, pendidikan formal, pengalaman berusahatani dan luas lahan usahatani.

Efektivitas pelaksanaan penyuluhan pertanian dinilai berdasarkan tugas pokok dan fungsi penyuluh pertanian pada masa pandemi Covid 19, yaitu; kemampuan menyusun program penyuluhan, kemampuan melaksanakan aksi sosial, kemampuan menerapkan protokol kesehatan, kemampuan mengelola informasi penyuluhan, kemampuan memanfaatkan sumber daya lokal, kemampuan membangun relasi interpersonal, kemampuan mengelola kelompok tani, dan kemampuan memotivasi pelaksanaan usahatani.

Persepsi petani terhadap pelaksanaan penyuluhan dinilai berdasarkan kompetensi, kemandirian dan motivasi penyuluh pertanian dalam mendampingi petani pada masa pandemi Covid 19, yaitu; kompetensi mengapresiasi keragaman budaya, kompetensi merencanakan program penyuluhan, kompetensi kepemimpinan penyuluh, kompetensi bidang keahlian penyuluh, kemandirian intelektual penyuluh, kemandirian ekonomi penyuluh, kemandirian sosial penyuluh dan kemandirian emosional penyuluh, motivasi untuk berprestasi dan motivasi berafiliasi.

Interpretasi efektivitas pelaksanaan penyuluhan pertanian terdiri dari 8 atribut pernyataan dengan rentang skala Likert yang digunakan, yaitu: 1 (Sangat Tidak Efektif), 2 (Kurang Efektif), 3 (Cukup Efektif), 4 (Tidak Efektif), 5 (Efektif) dan 6 (Sangat Efektif). Interpretasi persepsi petani pada pelaksanaan penyuluhan terdiri dari 10 atribut pernyataan dengan rentang skala Likert yang digunakan, yaitu: 1 (Sangat Tidak Baik), 2 (Kurang Baik), 3 (Cukup Baik), 4 (Tidak Baik), 5 (Baik) dan 6 (Sangat Baik). Untuk mengetahui efektivitas dan persepsi petani terhadap pelaksanaan penyuluhan pertanian pada masa pandemi Covid 19 dianalisis menggunakan semantic diferensial (Simamora, 2004) dengan rumus:

\section{$\{\mathbf{a}(\mathbf{m}-\mathbf{n})\} / \mathbf{b}$}

\section{Keterangan:}

$\mathrm{a}=$ Jumlah atribut $\mathrm{n}=$ Skor terendah yang mungkin terjadi 
Berdasarkan rumus semantic diferensial tersebut, maka interpretasi efektivitas dan persepsi pelaksanaan penyuluhan pertanian pada masa pandemi Covid 19, diuji dengan interval sebagai berikut:

1. Analisis data skor pernyataan responden pada efektivitas pelaksanaan penyuluhan pertanian:

$$
\begin{aligned}
& \text { Angka tertinggi = } 6 \text { (Sangat Efektif) } \\
& \text { Angka terendah } \quad=1 \text { (Sangat Tidak Efektif) } \\
& \text { Jumlah atribut pernyataan }=8 \\
& \text { Interval Kelas }=\frac{(6 \times 8)-(1 \times 8)}{6} \\
& \text { Interval Kelas }=\frac{(48)-(8)}{6} \\
& \text { Interval Kelas }=6,7
\end{aligned}
$$

\section{Tabel 1.}

Skor pernyataan responden pada efektivitas pelaksanaan penyuluhan pertanian

\begin{tabular}{ccc}
\hline Nilai & Skor & Kategori \\
\hline 1 & $8-14,7$ & Sangat Tidak Efektif \\
2 & $14,8-21,5$ & Tidak Efektif \\
3 & $21,6-28,3$ & Kurang Efektif \\
4 & $28,4-35,1$ & Cukup Efektif \\
5 & $35,2-41,9$ & Efektif \\
6 & $41,10-47,8$ & Sangat Efektif \\
\hline
\end{tabular}

2. Analisis data efektivitas pelaksanaan penyuluhan pertanian pada tiap-tiap atribut pernyataan:

$$
\begin{aligned}
& \text { Skala Interval }=\frac{(6 \times 1)-\left(\begin{array}{lll}
1 & \times & 1
\end{array}\right)}{6} \\
& \text { Skala Interval }=\frac{(6)-(1)}{6} \\
& \text { Skala Interval }=0,83
\end{aligned}
$$

Interpretasi skor penilaian tiap-tiap atribut pernyataan responden dijelaskan pada Tabel 2.

\section{Tabel 2.}

Skor penilaian tiap-tiap atribut pernyataan efektivitas pelaksanaan penyuluhan pertanian

\begin{tabular}{ccc}
\hline Nilai & Skor & Kategori \\
\hline 1 & $1-1,83$ & Sangat Tidak Efektif \\
2 & $1,84-2,67$ & Tidak Efektif \\
3 & $2,68-3,51$ & Kurang Efektif \\
4 & $3,52-4,35$ & Cukup Efektif \\
5 & $4,36-5,19$ & Efektif \\
6 & $5,20-6,03$ & Sangat Efektif \\
\hline
\end{tabular}

3. Analisis data skor pernyataan responden pada persepsi pelaksanaan penyuluhan pertanian
Angka tertinggi
Angka terendah
$=6$ (Sangat Bak)
Jumlah atribut pernyataan $=10$

Interval Kelas $=\frac{(6 \times 10)-(1 \times 10)}{6}$
Interval Kelas $=\frac{(60)-(10)}{6}$
Interval Kelas $=8,33$ 
Tabel 3.

Skor pernyataan responden pada persepsi pelaksanaan penyuluhan pertanian

\begin{tabular}{ccc}
\hline Nilai & Skor & Kategori \\
\hline 1 & $10-18,33$ & Sangat Tidak Baik \\
2 & $18,34-26,67$ & Tidak Baik \\
3 & $26,68-35,01$ & Kurang Baik \\
4 & $35,02-43,35$ & Cukup Baik \\
5 & $43,36-51,69$ & Baik \\
6 & $51,70-60,03$ & Sangat Baik \\
\hline
\end{tabular}

4. Analisis data persepsi pelaksanaan penyuluhan pertanian pada tiap-tiap atribut pernyataan:

$$
\begin{aligned}
\text { Skala Interval } & =\frac{(6 \times 1)-\left(\begin{array}{lll}
6 & \times & 1
\end{array}\right)}{6} \\
\text { Skala Interval } & =\frac{(6)-(1)}{6} \\
\text { Skala Interval } & =0,83
\end{aligned}
$$

Tabel 4.

Skor penilaian tiap-tiap atribut pernyataan persepsi pelaksanaan penyuluhan pertanian

\begin{tabular}{ccc}
\hline Nilai & Skor & Kategori \\
\hline 1 & $1-1,83$ & Sangat Tidak Baik \\
2 & $1,84-2,67$ & Tidak Baik \\
3 & $2,68-3,51$ & Kurang Baik \\
4 & $3,52-4,35$ & Cukup Baik \\
5 & $4,36-5,19$ & Baik \\
6 & $5,20-6,03$ & Sangat Baik \\
\hline
\end{tabular}

\section{Hasil dan Pembahasan}

\subsection{Karakteristik Responden}

Berdasarkan hasil survei dan wawancara dengan responden petani, maka karakteristik petani yang menunjang persepsi petani adalah umur, pendidikan formal, pengalaman berusahatani dan luas lahan usahatani. Hasil penelitian ini dijelaskan pada Tabel 5.

Tabel 5.

Karakteristik responden petani jagung

\begin{tabular}{cccc}
$\begin{array}{c}\text { Umur petani } \\
\text { (tahun) }\end{array}$ & Pendidikan formal & $\begin{array}{c}\text { Pengalaman berusahatani } \\
\text { (tahun) }\end{array}$ & Luas lahan usahatani (Ha) \\
\hline $35-45$ & SD & $5-10$ & $<1$ \\
$46-56$ & SMP & $11-16$ & 1 \\
$58-68$ & SLTA & $17-22$ & $>1$ \\
\hline
\end{tabular}

Sumber: Data primer setelah diolah, 2020

Karakteristik individu merupakan bentuk identitas dan penguasaan bidang pekerjaan yang diimplementasikan oleh individu pada setiap pekerjaannya, hal ini ditentukan oleh kematangan usia dan pendidikan serta pengalaman kerja individu. Karakteristik petani merupakan gambaran dari ciri individu petani yang bekerja sebagai pelaku utama usahatani. Hal ini dapat dijelaskan melalui hasil penelitian yang menunjukkan bahwa kategori umur petani berkisar antara 35 - 68 tahun dan tingkat pendidikan umumnya SD sampai SLTA serta pengalaman berusahatani selama 5 - 22 tahun pada luas lahan jagung kurang dari 1 ha sampai 1 ha.

Hasil penelitian ini searah dengan hasil penelitian dari Agyei \& Lindsay (2021) menjelaskan bahwa karakteristik individu penyuluh dan petani merupakan faktor kemampuan individu dan lingkungan yang dapat menentukan keberhasilan pekerjaannya. Secara teoritis hasil penelitian ini sesuai dengan pendapat Lionberger (1960) dan Bandura (1977) yang menjelaskan bahwa, karakteristik individu adalah personal faktor yang berhubungan dengan semua aspek kehidupan dan lingkungan seperti: umur, pendidikan dan karakteristik psikologis, fleksibilitas mental, orientasi pada usahatani sebagai bisnisnya dan kemudahan menerima inovasi.

\subsection{Efektivitas Pelaksanaan Penyuluhan Pertanian pada Masa Pandemi Covid 19}

Efektivitas kerja merupakan ukuran dan kemampuan individu dalam mengimplementasikan tugas pokok dan fungsinya sebagai usaha mewujudkan tujuan organisasi. Pengukuran tingkat 
efektivitas pelaksanaan penyuluhan pertanian mengacu pada tugas pokok dan fungsi penyuluh pertanian selama pandemi Covid 19, yaitu; kemampuan menyusun program penyuluhan, kemampuan melaksanakan aksi sosial, kemampuan menerapkan protokol kesehatan, kemampuan mengelola informasi penyuluhan, kemampuan memanfaatkan sumber daya lokal, kemampuan membangun relasi interpersonal, kemampuan mengelola kelompok tani, dan kemampuan memotivasi pelaksana usahatani. Hasil penelitian tentang efektivitas pelaksanaan penyuluhan pertanian dijelaskan pada Tabel 6.

Tabel 6.

Efektivitas pelaksanaan penyuluhan pertanian pada masa pandemi Covid 19

\begin{tabular}{|c|c|c|c|c|c|}
\hline \multirow{2}{*}{ No } & \multirow{2}{*}{ Atribut pernyataan } & \multirow{2}{*}{ Skor } & \multirow{2}{*}{ Kategori } & \multicolumn{2}{|c|}{ Jawaban Responden } \\
\hline & & & & Orang & $\%$ \\
\hline 1 & $\begin{array}{l}\text { Kemampuan menyusun program } \\
\text { penyuluhan }\end{array}$ & 4,38 & Efektif & 60 & 100 \\
\hline 2 & $\begin{array}{l}\text { Kemampuan melaksanakan aksi } \\
\text { sosial }\end{array}$ & 4,25 & Efektif & 43 & 71,7 \\
\hline 3 & $\begin{array}{l}\text { Kemampuan menerapkan protokol } \\
\text { kesehatan }\end{array}$ & 3,57 & Cukup efektif & 35 & 58,3 \\
\hline 4 & $\begin{array}{l}\text { Kemampuan mengelola informasi } \\
\text { penyuluhan }\end{array}$ & 5,25 & Sangat efektif & 52 & 87,7 \\
\hline 5 & $\begin{array}{l}\text { Kemampuan memanfaatkan sumber } \\
\text { daya lokal }\end{array}$ & 4,67 & Efektif & 45 & 75 \\
\hline 6 & $\begin{array}{l}\text { Kemampuan membangun relasi } \\
\text { interpersonal }\end{array}$ & 5,43 & Sangat efektif & 60 & 100 \\
\hline 7 & $\begin{array}{l}\text { Kemampuan mengelola kelompok } \\
\text { tani }\end{array}$ & 5,55 & Sangat efektif & 57 & 95 \\
\hline 8 & $\begin{array}{l}\text { Kemampuan memotivasi } \\
\text { peningkatan produktivitas } \\
\text { usahatani }\end{array}$ & 5,21 & Sangat efektif & 60 & 100 \\
\hline & Jumlah & 38,31 & Efektif & & \\
\hline
\end{tabular}

Sumber: Data Primer Setelah Diolah, 2020

Hasil penelitian menunjukkan bahwa efektivitas pelaksanaan penyuluhan pertanian pada masa pandemi Covid 19 "Efektif", dengan skor 38,31 artinya adanya penyuluhan yang dilakukan oleh penyuluh pertanian secara kontinyu kepada petani pada masa pandemi Covid 19 yang sesuai dengan tujuan program penyuluhan dan petunjuk protokol kesehatan, berdampak pada perubahan pola pikir, sikap dan kemampuan petani dalam mengelola usahatani pada masa pandemi Covid 19. Hal ini menunjukkan bahwa kemampuan pengetahuan dasar, sikap, keterampilan dan perilaku penyuluh pertanian dalam menjalankan tugas pokok dan fungsinya sangat berperan dalam menentukan efektivitas pelaksanaan penyuluhan serta sebagai bentuk pertanggungjawaban penyuluh terhadap pencapaian tujuan, visi dan misi lembaga penyuluhan pertanian.

Hasil penelitian ini sesuai dengan hasil penelitian dari Lannon \& John (2020) yang menyimpulkan bahwa efektivitas merupakan kemampuan menjalankan tugas pokok dan fungsi sesuai dengan tujuan organisasi. Program kerja akan berhasil jika disesuaikan dengan tujuan, visi dan misi organisasi. Sejalan dengan hasil penelitian, Menteri Pertanian RI mengamanatkan bahwa keberpihakan terhadap petani tetap terus ditingkatkan dengan optimalisasi dan efektivitas peran penyuluh pertanian. Pandemi covid-19 tidak menjadi penghalang penyuluh untuk terus mendampingi petani. Melalui wadah Kostratani yang dilengkapi teknologi informasi digital, sehingga pendampingan penyuluh pertanian bisa dilakukan secara efektif sesuai dengan petunjuk protokol kesehatan. Hal ini perlu ditunjang oleh optimalisasi lahan usahatani di seluruh Indonesia yang perlu didukung oleh gerakan antar lintas sektoral (Menteri Pertanian RI, 2020).

\subsection{Persepsi Petani pada Pelaksanaan penyuluhan pertanian di Masa Pandemi Covid 19}

Persepsi petani pada pelaksanaan penyuluhan merupakan bagian dari partisipasi petani yang berdampak pada peningkatan pengetahuan dan keterampilan petani dalam melaksanakan usahatani. Persepsi petani diwujudkan melalui proses adopsi inovasi teknologi pertanian yang disampaikan oleh penyuluh sesuai dengan kemampuan petani dan keadaan agroekosistem pertanian di sekitar petani. Persepsi petani pada pelaksanaan penyuluhan pertanian di masa pandemi Covid 19 dijelaskan melalui kompetensi, kemandirian dan motivasi penyuluh, seperti terlihat pada Tabel 7 . 
Tabel 7.

Persepsi petani pada pelaksanaan penyuluhan di masa pandemi Covid 19

\begin{tabular}{|c|c|c|c|c|c|}
\hline \multirow{2}{*}{ No } & \multirow{2}{*}{ Atribut pernyataan } & \multirow{2}{*}{ Skor } & \multirow{2}{*}{ Kategori } & \multicolumn{2}{|c|}{ Jawaban Responden } \\
\hline & & & & Orang & $\%$ \\
\hline 1 & $\begin{array}{ll}\text { Kompetensi } & \text { mengapresiasi } \\
\text { keragaman budaya } & \end{array}$ & 5,13 & Sangat baik & 60 & 100 \\
\hline 2 & $\begin{array}{l}\text { Kompetensi merencanakan program } \\
\text { penyuluhan }\end{array}$ & 5,23 & Sangat baik & 57 & 95 \\
\hline 3 & Kompetensi kepemimpinan penyuluh & 4,38 & Baik & 60 & 100 \\
\hline 4 & Kompetesi bidang keahlian penyuluh & 4,15 & Cukup baik & 45 & 75 \\
\hline 5 & Kemandirian intelektual penyuluh & 4,45 & Baik & 60 & 100 \\
\hline 6 & Kemandirian ekonomi penyuluh & 3,55 & Cukup baik & 35 & 58,3 \\
\hline 7 & Kemandirian sosial penyuluh & 4,64 & Baik & 52 & 86,7 \\
\hline 8 & Kemandirian emosional penyuluh & 3,47 & Baik & 55 & 91,7 \\
\hline 9 & Motivasi untuk berprestasi & 5,35 & Sangat baik & 60 & 100 \\
\hline 10 & Motivasi berafiliasi & 5,65 & Sangat baik & 40 & 66,7 \\
\hline & Jumlah & 46,00 & Baik & & \\
\hline
\end{tabular}

Sumber: Data Primer Setelah Diolah, 2020

Persepsi petani pada pelaksanaan penyuluhan pertanian di masa pandemi Covid 19 berada pada kategori "Baik", dengan skor 46,00, artinya petani masih membutuhkan penyuluhan pertanian dalam mengelola pada masa pandemi Covid 19. Hal mengindikasikan bahwa kompetensi, kemandirian dan motivasi penyuluh merupakan faktor kunci kualitas sumber daya manusia penyuluh pertanian yang perlu dipertahankan dan ditingkatkan oleh lembaga penyuluhan dalam mencapai tujuan penyuluhan pertanian, yaitu terjadinya perubahan perilaku petani dalam berusahatani.

Hasil penelitian ini searah dengan hasil penelitian dari Moyo \& Abiodun (2018) yang menjelaskan bahwa kompetensi, kemandirian dan motivasi penyuluh pertanian merupakan faktor yang menentukan dalam pencapaian tujuan lembaga penyuluhan, hal ini merupakan manifestasi dari kualitas sumber daya manusia penyuluh dalam melaksanakan tugas pokok dan fungsinya mendampingi petani berusahatani. Secara teoritis hasil penelitian ini sesuai dengan pendapat dari Boyatzis (1982), Gilley dan Eggland (1989), yang menjelaskan bahwa kompetensi, kemandirian dan motivasi merupakan kemampuan seseorang untuk menunjukkan kegiatan-kegiatan yang bersifat spesifik dalam satu lingkungan kerja yang dilakukan dengan penuh tanggungjawab, sehingga yang bersangkutan dapat menyelesaikan peran dan pekerjaan yang dibebankan kepadanya.

\section{Kesimpulan}

Efektivitas pelaksanaan penyuluhan pertanian pada masa pandemi Covid 19 "Efektif" dengan skor 38,31, karena pelaksanaan penyuluhan didasarkan pada kemampuan penyuluh dan program penyuluhan serta petunjuk protokol kesehatan, sehingga berdampak pada perubahan pola pikir, sikap dan kemampuan petani dalam mengelola usahatani pada masa pandemi Covid 19. Persepsi petani pada pelaksanaan penyuluhan pertanian di masa pandemi Covid 19 berada pada kategori "Baik", dengan skor 46,00, artinya petani masih membutuhkan penyuluhan pertanian dalam mengelola usahatani pada masa pandemi Covid 19, karena didasarkan pada kompetensi, kemandirian, dan motivasi penyuluh yang merupakan faktor utama sumber daya manusia penyuluh dalam pelaksanaan penyuluhan pertanian.

\section{Pustaka}

Acter, T., Nizam, U., Jagotamoy, D., Afroza, A., Tasrina, R.C, \& Sunghwan, K. (2020). Evolution of severe acute respiratory syndrome coronavirus 2 (SARS-CoV-2) as coronavirus disease 2019 (COVID-19) pandemic: A global health emergency. 730 (8): 1 - 19. https://doi.org/10.1016/j.scitotenv.2020.138996.

Agyei, P.A., \& Lindsay, C.S. 2021. Improving the effectiveness of agricultural extension services in supporting farmers to adapt to climate change: Insights from northeastern Ghana. Journal Climate Risk Management. 32 (3). 1 - 10. https://doi.org/10.1016/j.crm.2021.100304.

Bandura, A. 1977. Social Learning Theory. Englewood Cliffs, New Jersey: Prentice-Hall, Inc.

Bhandari, S., Matthew, R.H., \& Joshua, C. 2019. Making construction safety training interesting: A field-based quasi-experiment to test the relationship between emotional arousal and 
situational interest among adult learners. Journal Safety Science. 117 (8). 58 - 70. https://doi.org/10.1016/j.ssci.2019.03.028.

Boyatzis, R.E. 1982. The Compotent Manager, A Model for Effective Performance. New York: John Wiley and Sons.

Cook, B.R., Paula, S., \& Jayne, C. 2021. Humanising agricultural extension: A review. Journal World Development. 140 (4). 1 - 14. https://doi.org/10.1016/j.worlddev.2020.105337.

Gilley, W.J., \& Eggland, S.A. 1989. Principles of Human Resources Development. Toronto. Canada: Addison Wesley Publishing Company, Inc.

Harper, A., Navonil, M., \& Mike, Y. (2021). Facets of trust in simulation studies. European Journal of Operational Research. 289 (1): 197 - 213. https://doi.org/10.1016/j.ejor.2020.06.043.

Hunt, W., Colin, B., Frank, V., \& Jeff, C. 2014. Recommendations arising from an analysis of changes to the Australian agricultural research, development and extension system. Journal Food Policy. 44 (2). 129 - 141. https://doi.org/10.1016/j.foodpol.2013.11.007.

Johnson, L.K., Dara, J.B., Rebecca, D.D., Chris, C.G., Michael, D.B., \& Nancy, G.C. 2019. Farmer harvest decisions and vegetable loss in primary production. Journal Agricultural Systems. 176 (11). 1 - 11. https://doi.org/10.1016/j.agsy.2019.102672.

Khairad. F. (2020). Sektor pertanian di tengah pandemi COVID-19 ditinjau dari aspek agribisnis.

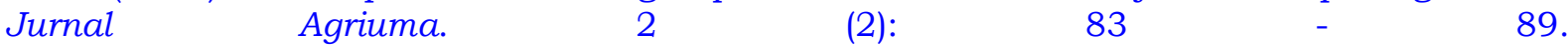
https://ojs.uma.ac.id/index.php/agriuma/article/view/4357/pdf.

Krausmann, E., \& Amos, N. 2021. Thinking the unthinkable: A perspective on Natech risks and Black Swans. Journal Safety Science. $139 \quad$ (7). 1 - 11. https://doi.org/10.1016/j.ssci.2021.105255.

Kuehne, G., Rick, L., David, J.P., Roger, W., Perry, D., Jackie, O., \& Mike, E. 2017. Predicting farmer uptake of new agricultural practices: A tool for research, extension and policy. Journal Agricultural Systems. 156 (9). 115 - 125. https://doi.org/10.1016/j.agsy.2017.06.007.

Lannon, J., \& John, N.W. 2020. Project facilitation as an active response to tensions in international development programmes. International Journal of Project Management. 38 (8). 486 - 499. https://doi.org/10.1016/j.ijproman.2020.06.002.

Lionberger, F.H. 1960. Adoption of New Ideas and Practices. Ames, Iowa: The Iowa State University Press.

Liu, W., Xue, F.S., Chia, H.W., \& Ping, Q. 2019. A systematic literature review on applications of information and communication technologies and blockchain technologies for precision agriculture development. Journal of Cleaner Production. 298 (5). 1 - 12. https://doi.org/10.1016/j.jclepro.2021.126763.

Menteri Pertanian RI. 2020. Strategi Pertanian Menghadapi Pandemi Covid-19. https://mediaindonesia.com/opini/308928/strategi-pertanian-menghadapi-pandemi-covid19.

Moyo, R., \& Abiodun, S. 2018. A survey of communication effectiveness by agricultural extension in the Gweru district of Zimbabwe. Journal of Rural Studies. 60 (5). 32 - 42. https:// doi.org/10.1016/j.jrurstud.2018.03.002.

Simamora, B. 2004. Riset Pemasaran. Gramedia Utama. Jakarta.

Slimi, C., Magali, P., Marianne, C., \& Lorène, P. 2021. Exchanges among farmers' collectives in support of sustainable agriculture: From review to reconceptualization. Journal of Rural Studies. 83 (4). 268 - 278. https://doi.org/10.1016/j.jrurstud.2021.01.019.

Taylor, M., \& Suhas, B. 2018. Model farmers, extension networks and the politics of agricultural knowledge transfer. Journal of Rural Studies. $64 \quad$ (11). 1 - 10. https://doi.org/10.1016/j.jrurstud.2018.09.015. 